JBEE: JOURNAL BUSINESS, ECONOMIC AND ENTREPRENEURSHIP

https://journal.shantibhuana.ac.id/index.php/bee/index

JBEE Volume 3 No 12021

\title{
KINERJA KEUANGAN CREDIT UNION KELING KUMANG BRANCH OFFICE SAYAN KABUPATEN MELAWI BERDASARKAN PEARLS
}

\author{
Simon Ahie
}

Sekolah Tinggi Ilmu Ekonomi "Indonesia" Pontianak
ahie.simon@gmail.com

\begin{abstract}
Abstrak
Sistem penilaian kinerja keuangan yang lebih sesuai untuk mengukur kinerja keuangan Credit Union, berdasarkan PEARLS. Tujuan dari Penelitian ini dilakukan adalah untuk mengetahui kinerja keuangan Credit Union Keling Kumang Sayan. Metode pengumpulan data yang digunakan adalah Observasi langsung.

Metode penelitian yang peneliti gunakan adalah metode penelitian deskriftif. Teknik analis data yang digunakan untuk menjawab kedua permasalahan tersebut adalah analisis PEARLS.

Hasil penelitiaan dari perhitungan pada tahun 2016-2018 rasio Perlindungan untuk P1 dan P2 tidak ideal, Struktur Keuangan Efektif untuk E1 tidak ideal, E5, Kualitas Aset untuk Al tidak ideal, Likuiditas untuk L1 tidak ideal, Tanda-tanda Pertumbuhan untuk S10 tidak ideal S11 tidak ideal. dengan nilai presentasenya yang berarti masuk dalam kategori buruk (tidak sehat), walaupun pada tahun 2016-2018 Untuk struktur keuangan yang efektif E5, E7, E8 ideal, nilai pengembalian dan biaya R7, R9 ideal, likuiditas L3 ideal, berarti nilai presentasenya sudah ideal/sehat karena mencapai keretria PEARLS.
\end{abstract}

Kata Kunci: Protection, Effectiv Financial Structure, Asset Quality, Rate of return and costs, Liquidity dan Signs of growth. 


\section{PENDAHULUAN}

\section{Latar Belakang}

Credit Union adalah koperasi keuangan yang tidak semata-mata mencari keuntungan (non for profit) kehadirannya bertujuan melayani para anggota yang berada dalam satu ikatan pemersatu (common-bond) seperti wilayah tempat tinggal, profesi, tempat kerja, dan lain-lain. Tujuan utama Credit Union adalah melayani para anggota agar permasalahan dan kebutuhan keuangan mereka teratasi. Credit Union dioperasikan secara demokrasi oleh para anggotanya dan diurus oleh para pengurus dan pengawas yang melayani anggota secara suka rela. Pengurus pun dipilih sendiri oleh anggota pada waktu rapat anggota.

David C. Richardson (2009), Executive Manager, Word Council of Credit Unions (WOCCU), seorang pengarang PEARLS mengatakan bahwa belajar dari pengalaman krisis keuangan global yang terjadi pada waktu yang lalu bahkan masih terasa sampai saat ini, agar terhindar dari krisis, Credit Union harus fokus pada penguatan dua hal yaitu keberlanjutan ekonomi dan keberlanjutan sosial. Apabila

Credit Union tidak aman dan tidak sehat, maka citra Credit Union akan buruk dan hal ini akan membahayakan Credit Union. Tidak ada orang yang percaya kepada Credit Union yang tidak sehat dan tidak aman (Munaldus dkk. 2011:20). Credit Union di Indonesia kini bukan lagi sekedar lembaga keuangan, tetapi sudah menjadi gerakan ekonomi karena besar dan luasnya dampak yang dihasilkan Credit Union. Sebuah Credit Union bisa saja tidak berhasil menacapai tujuan dari tujuan utama jika anggota Credit Union itu sendiri menabung di Credit Union untuk tujuan konsumtif dengan simpanan yang kurang baik, yaitu bunga atau dividen di bawah inflasi, oleh karena itu sebaiknya anggota Credit Union juga harus memiliki pinjaman untuk usaha-usaha produktif dan bukan semata-mata pinjaman untuk tujuan konsumtif. Selain itu sebuah Credit Union juga harus memperhatikan tingkat kesehatan keuangan yang dimilikinya. Selain untuk mengevaluasi kinerja keuangan, laporan keuangan berfungsi untuk memprediksi kemungkinan yang akan terjadi pada Credit Union di masa mendatang dengan informasi-informasi dan tanda-tanda yang diterima pada masa sebelumnya. Dengan demikian bisa membantu para manager untuk mengambil keputusan untuk tahun berikutnya. Ada beberapa sistem penilaian yang digunakan untuk mengukur kinerja keuangan di antaranya balance scorecard, CAMEL, analisis rentabilitas dan solvabilitas, tetapi sistem penilaian ini dinilai kurang mampu untuk mengukur kinerja keuangan secara menyeluruh menurut WOCCU (World Council of Credit Union), sehingga WOCCU mengembangkan sistem penilaian kinerja keuangan yang lebih sesuai untuk mengukur kinerja keuangan Credit Union, yaitu PEARLS.

PEARLS merupakan singkatan dari protection (perlindungan), effective financial structure (struktur keuangan yang efektif), asset quality (kualitas aset), rate of return and cost (nilai pengembalian dan biaya), liquidity (likuiditas), and sign of growth (tanda-tanda pertumbuhan). PEARLS berisi sekumpulan rasio yang dapat menggambarkan keadaan kinerja keuangan sebuah Credit Union.

Berdasarkan uraian di atas penelitian ini bertujuan untuk mengetahui kinerja keuangan Credit Union Keling Kumang Branch Office Sayan, dengan judul "Analisis Kinerja Keuangan Credit Union Keling Kumang Branch Office Sayan Kabupaten Melawi Berdasarkan PEARLS" dengan studi kasus pada Credit Union (CU) Keling Kumang Branch Office Sayan.

\section{Kajian Teori \\ Analisis Laporan Keuangan}

Analisis laporan keuangan terdiri dari dua kata yaitu analisis dan laporan keuangan. Analisis adalah memecahkan atau menguraikan sesuatu unit menjadi berbagai unit terkecil. Laporan keuangan adalah neraca, laporan laba-rugi, laporan aliran kas. Jadi analisis laporan keuangan sebagai mana dikemukakan oleh Harahap (2011: 190), yaitu: "penguraian pos-pos laporan keuangan menjadi unit informasi yang lebih kecil dan melihat hubungannya yang bersifat signifikan atau mempunyai makna antara satu dengan 
yang lain baik antara data kuantitatif maupun data non kuantitatif dengan tujuan untuk mengetahui kondisi keuangan lebih dalam yang sangat penting dalam menghasilkan keputusan yang tepat".

Dari uraian di atas dapat disimpulkan bahwa analisa laporan keuangan mencakup semua pos-pos laporan keuangan dan menjelaskan semua pos-pos tersebut sehingga dapat dimengerti dengan mudah dan dapat digunakan untuk mengambil keputusan bagi pihak-pihak yang berkepentingan.

\section{Analisis PEARLS}

Menurut Richardson (Munaldus dkk, 2011: 166) "PEARLS adalah suatu sistem monitoring kinerja keuangan yang dirancang guna membantu manajemen Credit Union dalam mengelola keuangannya dan digunakan untuk menilai tingkat kesehatan yang dikembangkan oleh WOCCU (World Council of Credit Union)".

Analisis PEARLS adalah sarana yang dapat digunakan oleh Credit Union di Asia. Karena ini adalah ukuran standar bagi Credit Union yang layak hidup terus dan dapat memperahankan keberadaannya di pasar keuangan. Celah yang teridentifikasi adalah kelemahan yang perlu diperbaiki dan menjadi fokus pengelolan masa depan Credit Union.

Ada 4 kegunaan PEARLS sebagai berikut:

1. Sebagai alat untuk memantau kinerja Credit Union

2. Menstandarkan rasio dan rumus

3. Dapat digunakan untuk merangking suatu $\mathrm{CU}$

4. Sebagai alat pengawasan

\section{Credit Union}

Kata Credit Union berasal dari bahasa latin, Credere yang berarti percaya dan Union yang berarti kumpulan/kesatuan (mengikat diri dalam suatu kesatuan). Jadi CU (Credit Union) adalah badan usaha yang dimiliki oleh sekumpulan orang yang saling percaya dalam ikatan pemersatu, yang bersepakat untuk menabungkan uang mereka sehingga menciptakan modal bersama guna dipinjamkan di antara sesama mereka dengan bunga yang layak untuk tujuan produktif dan kesejahteraan.

Credit Union adalah salah satu solusi pemberdayaan ekonomi yang bisa melibatkan banyak kalangan masyarakat, lintas agama bahkan lintas usia, agar mereka bertanggungjawab akan masa depannya masing-masing. Yang pra sejahtera bisa naik sedikit menjadi lebih sejahtera; yang sudah sejahtera pun bisa memiliki nilai sosial dari uang simpanannya untuk digunakan bagi mereka yang membutuhkan. Bukan sekedar charity atau donasi, tetapi menjadi modal untuk mengangkat taraf hidup mereka sendiri.

Credit Union kini tidak hanya berfungsi sebuah lembaga yang hanya mengelola keuangan, Credit Union juga merupakan sebuah gerakan yang didasari oleh sikap saling percaya. Tujuannya adalah untuk saling memberdayakan, memperkuat solidaritas, dan memperkokoh kesejahteraan masyarakat di mana pelakunya adalah anggota itu sendiri. dari anggota, oleh anggota, dan untuk anggota. Pemberdayaan di segala aspek kehidupan anggota, mulai dari aspek ekonomi, moralsosial, politik, dan hukum.ini memperjelas bahwa CU bukan hanya sebagai sebuah lembaga yang hanya mengelola keuangan saja. Credit Union lahir dari pendidikan, berkembang melalui pendidikan dan bergantung dari pendidikan, oleh karena itu setiap calon anggota (masyarakat) yang akan bergabung dengan $\mathrm{CU}$ wajib untuk mengikuti pendidikan. Tujuan utama pendidikan adalah untuk mengenal dan memperdalam seluk beluk Credit Union, penyamaan visi misi sebagai anggota Credit Union, perubahan-perubahan aspek mental, emosional, perubahan prinsip dan paradigma hidup.

Credit Union merupakan kumpulan orangorang dari latar belakang berbeda. Ada pedagang, petani, pegawai, pengusaha, buruh dan sebagainya yang mau bekerja sama. Orang-orang tersebut mengumpulkan uang untuk modal bersama dan dipinjamkan kepada sesama pula.

Prinsip Utama Membangun Credit Union 
a) Tabungan Hanya Dapat di peroleh Dari anggotanya (Swadaya).

b) Pinjaman hanya diberikan kepada anggotanya saja.

c) Jaminan terbaik si peminjam adalah watak si peminjam itu sendiri.

Tujuan Mendirikan CU:

1. Membimbing dan mengembangkan sikap hemat menghadapi tantangan konsumerisme disekeliling kita.

2. Memberikan pinjaman layak, tepat, cepat dan murah; terutama bagi mereka yang tidak memiliki aset yang dapat dijaminkan ke lembaga keuangan.

3. Membiasakan anggota agar menggunakan uang dengan bijaksana. Think twice, Act wise. Para pengurus akan membimbing bagaimana memilih simpanan dan menggunakan pinjaman. Pembentukan karakter adalah salah satu prasyarat bagi permohonan kredit.

4. Agar anggota dapat merancang masa depan yang lebih baik tidak hanya menghadapi kesulitan sekarang, tapi juga memikirkan masa depan anak-anaknya.

\section{METODE PENELITIAN}

Dalam penelitian, metode merupakan suatu hal atau cara yang penting untuk mencapai suatu tujuan yang diinginkan oleh seorang peneliti, dalam hubungannya dengan peneliti, maka pengertian dari metode itu banyak macam. Menurut Sugiyono (2017:2) mengatakan "metode penelitian pada dasarnya merupakan cara ilmiah untuk mendapatkan data dengan tujuan dan kegunanya tertentu". Dengan kata lain, metode adalah suatu cara yang menggunakan teknik untuk mencapai suatu tujuan melalui data-data yang relevan sehingga dapat diukur dengan suatu alat ukur yang pasti. Bentuk penelitian yang peneliti gunakan metode deskriptif berupa studi kasus dengan objek Credit Union Keling Kumang Branch Office Sayan.

\section{Teknik Analisis Data}

Adapun teknik analisis data yang digunakan dalam penelitian ini berdasarkan PEARLS adalah:

\section{1) Perlindungan (Protection)}

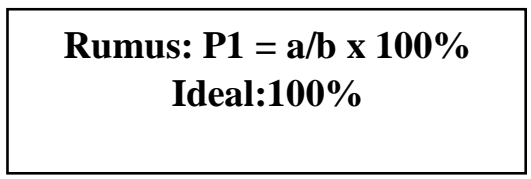

Indikator ini mengukur kecukupan dana cadangan, cadangan risiko dan provisi kredit lalai.

1) Ketersediaan dana cadangan risiko dan provisi pinjaman lalai/total pinjaman macet $>12$ bulan $(\mathrm{P} 1)$

Tujuan: mengukur ketersediaan dana cadangan, cadangan risiko dan provisi pinjaman lalai yang digunakan untuk menutup total pinjaman macet $>12$ bulan

Keterangan:

a) Dana cadangan risiko + provisi pinjaman lalai (lihat di pasiva)

b) Total pinjaman lalai

2) Ketersediaan dana cadangan risiko dan provisi pinjaman lalai bersih atau total pinjaman lalai 1-12 bulan.

Tujuan: Mengukur ketersediaan dana cadangan risiko dan provisi pinjaman lalai bersih (di luar dana cadangan risiko untuk P1) untuk melindungi pinjaman lalai 1-12 bulan.

Keterangan:

a) Total dana cadangan risiko dan provisi diluar untuk P1

b) Total pinjaman lalai 1 sampai 12 bulan

\section{Rumus: P2 = a/b x 100\% Ideal: $\mathbf{3 5 \%}$}

\section{2) Struktur Keuangan Efektif (Effective Financial Structure)}

Indikator ini mengukur perbandingan komposisi dari nomor nomor perkiraan yang 
paling penting pada neraca keuangan. Struktur keuangan yang efektif perlu untuk mencapai tingkat aman (safety), kesehatan (soundness), dan keuntungan (profitability), sementara pada saat yang sama Credit Union Branch Office Sayan mempromosikan diri agar mampu mencapai pertumbuhan nyata yang agresif.

1) Aset-aset yang menghasilkan:

a) Rasio Piutang yang beredar (E1)

Tujuan: mengukur persentase piutang pada total aset yang diinvestasikan dalam portofolio pinjaman (total aset).

Keterangan:

(1) Saldo pinjaman beredar

(2) Total aset

Rumus: $\mathbf{E 1}=\mathrm{a} / \mathrm{b} \times 100 \%$

Ideal: $\mathbf{7 0 \% - 8 0 \%}$

b) Rasio pinjaman non-saham (E5)

Tujuan: mengukur persentase total aktiva yang didanai dengan simpanan non-saham.

Keterangan:

(1) Total simpanan non-saham

(2) Total aset

Rumus: $\mathbf{E} 5=\mathrm{a} / \mathrm{b} \times \mathbf{1 0 0 \%}$

Ideal: $\mathbf{7 0 \%}-\mathbf{8 0 \%}$

c) Rasio pinjaman dari luar

Tujuan: mengukur presentae simpanan saham yang didanai dari modal saham.

Keterangan:

(1) Total simpanan saham

(2) Total aset

Rumus: E6 $=(a+b) \times 100 \%$

Ideal: $10-20 \%$

\section{c. Kualitas Aset (Asets Quality)}

Indikator A mengukur persentase aset-aset yang tidak menghasilkan berdampak negatif terhadap perolehan keuntungan dan solvency (ketahanan). E terdiri atas pinjaman lalai (delinquency), asetaset yang tidak menghasilkan dan pendananaan aset-aset yang tidak menghasilkan.

1) Total pinjaman lalai (A1)

Tujuan: mengukur persentase total pinjaman lalai di portofolio pinjaman, menggunakan kriteria saldo pinjaman yang lalai yang sudah di-charge-off yang masih dalam masa penagihan.

Keterangan:
a) Total saldo pinjaman lalai
b) Total pinjaman beredar

$$
\begin{gathered}
\text { Rumus: A1 }=\mathbf{a} / \mathbf{b} \times 100 \% \\
\text { Ideal: } \leq \mathbf{5 \%}
\end{gathered}
$$

\section{2) Aset-aset yang tidak menghasilkan (A2)}

Tujuan: mengukur persentase total aset yang tidak menghasilkan pendapatan. Yang termasuk aset-aset yang tidak menghasilkan: uang tunai kas/brankas, cash-bond, materai, biaya di bayar di muka, persediaan, aset-aset tetap (tanah, gedung, kendaraan, perlengkapan), aktiva dalam penyelesaian dan aset-aset bermasalah.

Keterangan:

a)

b)

Total aset yang tidak menghasilakan Total aset

$$
\begin{gathered}
\text { Rumus: } \mathrm{A} 2=\mathrm{a} / \mathrm{b} \times 100 \% \\
\text { Ideal: } \leq \mathbf{5 \%}
\end{gathered}
$$

\section{d. Nilai Pengembalian dan Biaya (Rates of Returns and Costs)}

Indikator ini mengukur pendapatan perolehan rata-rata untuk setiap aset yang paling produktif yang tercantum pada neraca. Disamping itu, $\mathrm{R}$ mengukur biaya rata-rata untuk setiap utang dan modal yang paling penting. Hasilnya merupakam perolehan investasi rata-rata dan bukan hasil "spread analysis" khusus yang digambarkan berdasarkan pada basis rata-rata aset. Hasil 
yang berkaitan menunjukkan apakah Credit Union Branch Office Sayan memperoleh pendapatan dan mampu membayar sesuai tingkat bunga pasar atas aset, utang dan modal.

1) Biaya keuangan : Simpanan saham anggota/ Rata-rata simpanan saham (R7)

Tujuan: mengukur pendapatan (biaya) atas simpanan saham anggota.

a) Total SHU

b) Total rata-rata aset

\section{Rumus R7 = (a/b) x 100\% \\ Ideal: R5}

2) Biaya operasional/rata-rata aset

Tujuan: mengukur biaya yang terkait dengan manajemen dari semua aset Credit Union Branch Office Sayan. Biaya ini diukur sebagai persentase total aset dan menunjukkan drajat efisiensi operasional atau ketidak efisiensian operasional.

Keterangan:

a) Total biaya operasional

b) Rata rata total aset

\section{Rumus: R9= $(\mathbf{a} / \mathbf{b}) \times 100 \%$} Ideal: $\mathbf{5 \%}$

\section{e. Likuiditas (Liquidity)}

Indikator ini menunjukkan apakah Credit Union Branch Office Sayan dapat secara efektif menangani uang tunainya sehingga Credit Union Branch Office Sayan selalu memiliki uang yang cukup mana kala secara tiba-tiba para anggota menarik simpanannya. Dengan kata lain cadangan likuidits selalu kuat. Di samping itu, uang menganggur (idle) juga diukur untuk memastikan bahwa aset-aset yang tidak menghasilkan jangan sampai mengurangi pendapatan Credit Union Branch Office Sayan.

1) Investasi likuid + aset Likuid - kewajiban jangka pendek/simpanan non-saham (L1)

Tujuan: mengukur kesehatan cadangan kas likuid untuk memenuhi tarikan simpanan, setelah membayar semua kewajiban jangka pendek < 30 hari (masuk dalam non-interest bearing liabilities)

Keterangan:

a) Aktiva lancar

b) Total simpanan non-saham

$$
\begin{gathered}
\text { Rumus: } L 1=(a+b-c) \times 100 \% \\
\text { Ideal: } \geq 15 \%
\end{gathered}
$$

3) Aset-aset Likuid yang Tidak Menghasilkan/Total Aset (L3)

Tujuan: mengukur persentase total aset yang diinvestasikan di dalam

nomor perkiraan (account) likuid yang tidak menghasilkan.

Keterangan:

a) Total aset-aset likuid yang tidak menghasilkan

b)

Total Aset

$$
\begin{gathered}
\text { Rumus: } \mathbf{L 3}=(a+b-c) \times 100 \% \\
\text { Ideal: } \geq 15 \%
\end{gathered}
$$

f.Tanda-Tanda Pertumbuhan (Sign of Growth) Indikator ini mengukur persentase pertumbuhan di setiap nomor perkiraan yang paling penting di laporan keuangan, juga pertumbuhan anggota. Dalam kondisi ekonomi dengan inflasi tinggi, pertumbuhan nyata (setelah dikurangkan dengan inflasi), merupakan kunci ketahanan jangka panjang Credit Union Branch Office Sayan.

1) Pertumbuhan anggota (S10)

Tujuan: mengukur pertumbuhan anggota Credit Union Branch Office Sayan tahun berjalan. keterangan:

a) Anggota Sekarang

b) Anggota tahun lalu

$$
\begin{gathered}
\text { Rumus: } \mathrm{S} 10=(\mathrm{a} / \mathrm{b}) \times 100 \% \\
\text { Ideal: }>12 \%
\end{gathered}
$$


2) Pertumbuhan total aset (S11)

Tujuan: mengukur pertumbuhan total aset tahun berjalan.

Keterangan:

a) Total aset sekarang

b) total aset tahun lalu

\begin{tabular}{c}
\hline Rumus: $\mathbf{S 1 1}=(\mathbf{a} / \mathbf{b}) \times 100 \%$ \\
Ideal: $10 \%$ \\
\hline
\end{tabular}

\section{HASIL DAN PEMBAHASAN}

\section{Perlindungan (Protection)}

Indikator ini mengukur kecukupan dana cadangan, cadangan risiko dan provisi kredit lalai.

a. Ketersediaan dana cadangan risiko dan provisi pinjaman lalai/total pinjaman macet $>12$ bulan $(\mathrm{P} 1)$

Tujuan: Mengukur kecukupan dana cadangan risiko bila dibandingkan dengan pinjaman lalai di atas 12 bulan.

Dari hasil perhitungan, dapat dilihat pada tahun 2016 sebesar 3,73\%, persentase ini menunjukkan tidak idealnya indikator P1 dengan kriteria tidak ideal / tidak sehat artinya pada tahun 2016 kecukupan dana cadangan risiko terhadap pinjaman lalai $>12$ mengalami penurunan berarti dalam kondisi yang tidak stabil karena kurang dari standar ideal rasio PEARLS $100 \%$

Pada tahun 2017 sebesar 4\% persentase ini menunjukkan tidak idealnya indikator P1 dengan kriteria tidak ideal / tidak sehat artinya pada tahun 2017 kecukupan dana cadangan risiko terhadap pinjaman lalai > 12 mengalami penurunan berarti dalam kondisi tidak yang stabil karena kurang dari standar ideal rasio PEARLS $100 \%$.

Pada tahun 2018 sebesar 4,05\%, persentase ini menunjukkan tidak idealnya indikator P1 dengan kriteria tidak ideal / tidak sehat artinya pada tahun 2018 kecukupan dana cadangan risiko terhadap pinjaman lalai > 12 mengalami penurunan berarti dalam kondisi tidak stabil karena kurang dari standar ideal rasio PEARLS $100 \%$.
Kesimpulannya untuk kecukupan dana cadangan atas pinjaman macet $>12$ pada tahun 2016-2018 persentase ini menunjukkan tidak idealnya indikator P1 dengan kriteria tidak ideal / tidak sehat artinya kecukupan dana cadangan terhadap pinjaman lalai $>12$ dalam posisi yang tidak stabil karena mengalami penurunan dari standar idealnya.

b. Ketersediaan dana cadangan risiko dan provisi pinjaman lalai bersih atau total pinjaman lalai 1-12 bulan. (P2)

Tujuan: Mengukur kecukupan dana cadangan risiko untuk menutup pinjaman lalai 1 - 12 bulan

Dari hasil perhitungan, dapat dikatakan pada tahun 2016 sebesar $-2729 \%$, persentase ini menunjukkan tidak idealnya indikator P2 dengan kriteria tidak ideal / tidak sehat artinya pada tahun 2016 ketersediaan dana cadangan risiko terhadap pinjaman lalai 1-12 mengalami kenaikkan berarti dalam kondisi tidak stabil karena lebih dari standar ideal rasio PEARLS $35 \%$.

Pada tahun 2017 sebesar $-3829 \%$, persentase ini menunjukkan tidak idealnya indikator P2 dengan kriteria tidak ideal / tidak sehat artinya pada tahun 2017 ketersediaan dana cadangan risiko terhadap pinjaman lalai 1-12 mengalami kenaikkan berarti dalam kondisi tidak stabil karena lebih dari standar ideal rasio PEARLS $35 \%$

Pada tahun 2018 sebesar $-7655 \%$, persentase ini menunjukkan tidak idealnya indikator P2 dengan kriteria tidak ideal / tidak sehat artinya pada tahun 2018 ketersedian dana cadangan risiko terhadap pinjaman lalai 1-12 mengalami kenaikkan berarti dalam kondisi tidak stabil karena lebih dari standar idealnya.

Kesimpulannya untuk ketersedian dana cadangan resiko atas pinjaman lalai 1-12 pada tahun 2016-2018 persentase ini menunjukkan tidak idealnya indikator P2 dengan kriteria tidak ideal/tidak sehat artinya ketersedian dana cadangan resiko atas pinjaman lalai 1-12 dalam posisi yang tidak stabil karena lebih dari standar idealnya. 


\section{Struktur Keuangan Yang Efektif (Effective Financial Structure)}

Indikator ini mengukur perbandingan komposisi dari nomor-nomor perkiraan yang paling penting pada neraca keuangan. Struktur keuangan yang efektif perlu untuk mencapai tingkat aman (safety), kesehatan (soundness), dan keuntungan (profitability), sementara pada saat yang sama Credit Union Branch Office Sayan mempromosikan diri agar mampu mencapai pertumbuhan nyata yang agresif.

\section{a. Pinjaman Beredar/Total Aset (E1)}

Tujuan: mengukur persentase total aset yang diinvestasikan di dalam pinjaman beredar

Dari hasil perhitungan, tahun 2016 sebesar $177 \%$, persentase ini menunjukkan tidak idealnya indikator E1 dengan kriteria tidak ideal / tidak sehat artinya pada tahun 2016 pinjaman beredar terhadap total aset mengalami kenaikkan berarti dalam kondisi yang tidak stabil karena nilai persentasenya lebih dari standar ideal rasio PEARLS 70-80\%. Pada tahun 2017 sebesar 156\%, persentase ini menunjukkan tidak idealnya indikator E1 dengan kriteria tidak ideal / tidak sehat artinya pada tahun 2017 pinjaman beredar terhadap total aset mengalami kenaikkan berarti dalam kondisi yang tidak stabil karena nilai persentasenya lebih dari standar ideal rasio PEARLS 70-80\%.

Pada tahun $2018155 \%$, persentase ini menunjukkan tidak idealnya indikator E1 dengan kriteria tidak ideal / tidak sehat artinya pada tahun 2018 pinjaman beredar terhadap total aset mengalami kenaikkan berarti dalam kondisi yang tidak stabil karena nilai persentasenya lebih dari standar ideal rasio PEARLS 70-80\%.

Kesimpulannya untuk pinjaman beredar terhadap total aset pada tahun 2016-2018 persentase ini menunjukkan tidak idealnya indikator E1 dengan kriteria tidak ideal / tidak sehat.

b. Simpanan Non Saham/Total Aset (E5)

Tujuan: Mengukur persentase total aset yang didanai oleh simpanan non-saham
Dari hasil perhitungan, pada tahun 2016 sebesar $68 \%$, persentase ini menunjukkan idealnya indikator E5 dengan kriteria ideal / sehat, artinya pada tahun 2016 simpanan non saham terhadap total aset dalam kondisi yang stabil karena nilai persentasenya mencapai standar ideal rasio PEARLS 70-80\%.

Pada pada 2017 sebesar 71\%, persentase ini menunjukkan idealnya indikator E5 dengan kriteria ideal / sehat, artinya pada tahun 2017 simpanan non saham terhadap total aset berarti dalam kondisi yang stabil karena nilai persentasenya lebih dari standar ideal rasio PEARLS 70-80\%.

Pada Tahun 2018 sebesar 70\%, persentase ini menunjukkan idealnya indikator E5 dengan kriteria ideal / sehat, artinya pada tahun 2018 simpanan non saham terhadap total aset dalam kondisi yang stabil karena nilai persentasenya mencapai standar ideal rasio PEARLS 70-80\%.

Kesimpulannya untuk simpanan non saham terhadap total aset pada tahun 2016-2018 persentase ini menunjukkan idealnya indikator E5 dengan kriteria ideal / sehat, artinya di tahun 2016-2018 dalam posisi yang stabil karena persentasenya mencapai standar ideal.

c. Modal Saham/Total Aset (E7)

Tujuan: Mengukur persentase total aset yang didanai dari modal saham

Dari hasil perhitungan pada tahun 2016 sebesar $19 \%$, persentase ini menunjukkan idealnya indikator E7 dengan kriteria ideal / sehat, artinya pada tahun 2016 modal saham terhadap total aset dalam kondisi yang stabil karena nilai persentasenya mencapai standar ideal rasio PEARLS 10-20\%.

Pada pada 2017 sebesar 19\%, persentase ini menunjukkan idealnya indikator E7 dengan kriteria ideal / sehat, artinya pada tahun 2017 modal saham terhadap total aset dalam kondisi stabil karena nilai persentasenya mencapai standar ideal rasio PEARLS 10-20\%.

Pada tahun 2018 sebesar 20\%, persentase ini menunjukkan idealnya indikator E7 dengan kriteria ideal / sehat, artinya pada tahun 2018 modal saham terhadap total aset dalam kondisi yang stabil karena nilai persentasenya mencapai standar ideal rasio PEARLS 10-20\%. 
Kesimpulannya untuk modal saham terhadap total aset pada tahun 2016-2018 persentase ini menunjukkan idealnya indikator E7 dengan kriteria ideal / sehat, artinya di tahun 20162018 dalam posisi yang stabil karena persentasenya mencapai standar ideal.

\section{d. Modal Lembaga/Total Aset (E8)}

Tujuan: Tujuan mengukur persentase total aset yang didanai oleh modal lembaga

Dari hasil perhitungan tabel 3.5 di atas dapat dikatakan pada tahun 2016 sebesar 30\%, persentase ini menunjukkan tidak idealnya indikator E8 dengan kriteria tidak ideal / tidak sehat, artinya pada tahun 2016 modal lembaga terhadap total aset dalam kondisi yang tidak stabil karena nilai persentasenya lebih dari standar ideal rasio PEARLS $10 \%$.

Pada pada 2017 sebesar 26\%, persentase ini menunjukkan tidak idealnya indikator E8 dengan kriteria tidak ideal / tidak sehat, artinya pada tahun 2017 modal lembaga terhadap total aset dalam kondisi yang tidak stabil karena nilai persentasenya lebih dari standar ideal rasio PEARLS $10 \%$.

Pada tahun 2018 28\%, persentase ini menunjukkan tidak idealnya indikator E8 dengan kriteria tidak ideal / tidak sehat, artinya pada tahun 2018 modal lembaga terhadap total aset dalam kondisi yang tidak stabil karena nilai persentasenya lebih dari standar ideal rasio PEARLS $10 \%$.

Kesimpulannya untuk modal lembaga terhadap total aset pada tahun 2016-2018 persentase ini menunjukkan idealnya indikator E8 dengan kriteria tidak ideal / tidak sehat, artinya di tahun 2016-2018 dalam posisi yang tidak stabil karena persentasenya lebih dari standar ideal.

\section{Kualitas Asset (Assets Quality)}

Indikator A mengukur persentase aset-aset yang tidak menghasilkan berdampak negatif terhadap perolehan keuntungan dan ketahanan. E terdiri atas pinjaman lalai, aset-aset yang tidak menghasilkan dan pendananaan aset-aset yang tidak menghasilkan.

a. Total pinjaman lalai (A1)

Tujuan: Mengukur persentase pinjaman lalai di dalam pinjaman beredar
Dari hasil perhitungan tabel 3.5 di atas dapat dilihat pada tahun 2016 sebesar 75\%, persentase ini menunjukkan tidak idealnya indikator A1 dengan kriteria tidak ideal/tidak sehat artinya pada tahun 2016 pinjaman lalai terhadap pinjaman beredar mengalami kenaikkan berarti dalam kondisi yang tidak stabil karena nilai persentasenya lebih dari standar ideal rasio PEARLS $<5 \%$.

Pada tahun 2017 sebesar 64\%, persentase ini menunjukkan tidak idealnya indikator A1 dengan kriteria tidak ideal/tidak sehat artinya pada tahun 2017 pinjaman lalai terhadap pinjaman beredar mengalami kenaikkan berarti dalam kondisi yang tidak stabil karena nilai persentasenya lebih dari standar ideal rasio PEARLS $<5 \%$.

Pada tahun 2018 59\%, persentase ini menunjukkan tidak idealnya indikator A1 dengan kriteria tidak ideal/tidak sehat artinya pada tahun 2018 pinjaman lalai terhadap pinjaman beredar mengalami kenaikkan berarti dalam kondisi yang tidak stabil karena nilai persentasenya lebih dari standar ideal rasio PEARLS $<5 \%$.

Kesimpulannya untuk pinjaman lalai terhadap pinjaman beredar pada tahun 2016-2018 persentase ini menunjukkan tidak idealnya indikator A1 dengan kriteria tidak ideal/tidak sehat, artinya di tahun 2016-2018 artinya di tahun 2016-2018 dalam posisi yang tidak stabil karena persentasenya lebih dari standar ideal.

b. Aset-aset yang tidak menghasilkan (A2)

Tujuan: mengukur persentase total aset yang tidak menghasilkan pendapatan.

Dari hasil perhitungan, pada tahun 2016 sebesar $0 \%$, persentase ini menunjukkan idealnya indikator A2 dengan kriteria ideal / sehat artinya pada tahun 2016 aset yang tidak menghasilkan terhadap total aset berarti dalam kondisi yang ideal / sehat karena nilai persentasenya $0 \%$ dari standar ideal rasio PEARLS $<5 \%$.

Pada tahun 2017 sebesar 0\%, persentase ini menunjukkan idealnya indikator A2 dengan kriteria ideal / sehat artinya pada tahun 2017 aset yang tidak menghasilkan terhadap total aset berarti dalam kondisi yang ideal / sehat 
karena nilai persentasenya $0 \%$ dari standar ideal rasio PEARLS $<5 \%$.

Pada tahun 2018 1\%, persentase ini menunjukkan idealnya indikator A2 dengan kriteria ideal / sehat artinya pada tahun 2018 aset yang tidak menghasilkan terhadap total aset berarti dalam kondisi yang ideal / sehat karena nilai persentasenya $1 \%$ dari standar ideal rasio PEARLS $<5 \%$.

Kesimpulannya untuk aset yang tidak menghasilkan terhadap total aset pada tahun 2016-2018 persentase ini menunjukkan idealnya indikator A2 dengan kriteria ideal / sehat, artinya di tahun 2016-2018 tingkat persentase aset yang tidak menghasilkan terhadap total aset dalam kondisi ideal / sehat.

\section{Nilai Pengembalian dan Biaya (Rates of Returns and Costs)}

Indikator nilai pengembaliaan dan biaya (Rates of return and cost) ini mengukur perolehan pendapatan rata- rata untuk setiap aset yang paling produktif yang tercantum pada neraca.

\section{a. Biaya Modal Saham/Modal Saham Rata- Rata (R7)}

Tujuan: Mengukur biaya BJS dan BJP untuk simpanan saham

Dari hasil perhitungan pada tahun 2016 sebesar $29 \%$, persentase ini menunjukkan idealnya indikator R7 dengan kriteria ideal / sehat artinya pada tahun 2016 biaya modal saham terhadap modal saham rata-rata berarti dalam kondisi yang stabil karena nilai persentasenya lebih dari standar ideal rasio PEARLS $>$ R5\%. Pada tahun 2017 sebesar $21 \%$, persentase ini menunjukkan idealnya indikator R7 dengan kriteria ideal / sehat artinya pada tahun 2017 biaya modal saham terhadap modal saham ratarata berarti dalam kondisi yang stabil karena nilai persentasenya lebih dari standar ideal rasio PEARLS $>$ R5\%.

Pada tahun 2018 17\%, persentase ini menunjukkan idealnya indikator R7 dengan kriteria ideal / sehat artinya pada tahun 2018 biaya modal saham terhadap modal saham ratarata berarti dalam kondisi yang stabil karena nilai persentasenya lebih dari standar ideal rasio PEARLS $>$ R5\%.

Kesimpulannya untuk biaya modal saham terhadap modal saham rata-rata pada tahun 2016-2018 persentase ini menunjukkan idealnya indikator R7 dengan kriteria ideal / sehat, artinya di tahun 2016-2018 tingkat persentase biaya modal saham terhadap modal saham rata-rata dalam kondisi ideal / sehat.

b. Biaya Operasional/Rata-rata aset

Tujuan: Mengukur biaya yang berkaitan dengan manajemen semua aset CU. biayabiaya ini diukur dengan persentase total aset dan menunjukkan derajat efisiensi operasional.

Dari hasil perhitungan pada tahun 2016 sebesar $5 \%$, persentase ini menunjukkan idealnya indikator R9 dengan kriteria ideal / sehat artinya pada tahun 2016 biaya operasional terhadap rata-rata aset berarti dalam kondisi yang stabil karena nilai persentasenya mencapai standar ideal rasio PEARLS $<10 \%$.

Pada tahun 2017 sebesar 5\%, persentase ini menunjukkan idealnya indikator R9 dengan kriteria ideal / sehat artinya pada tahun 2017 biaya operasional terhadap rata-rata aset berarti dalam kondisi yang stabil karena nilai persentasenya mencapai standar ideal rasio PEARLS $<10 \%$.

Pada tahun 2018 6\%, persentase ini menunjukkan -idealnya indikator R9 dengan kriteria ideal / sehat artinya pada tahun 2018 biaya operasional terhadap rata-rata aset berarti dalam kondisi yang stabil karena nilai persentasenya mencapai standar ideal rasio PEARLS $<10 \%$.

Kesimpulannya untuk biaya operasional terhadap rata-rata aset pada tahun 2016-2018 persentase ini menunjukkan idealnya indikator R9 dengan kriteria ideal / sehat artinya di tahun 2016-2018 tingkat persentase biaya operasional dalam kondisi ideal / sehat.

\section{Likuiditas (Liquidity)}

Indikator ini menunjukkan apakah Credit Union Keling Kumang Branch Office Sayan dapat secara efektif menangani uang tunainya sehingga Credit Union Keling Kumang Branch Office Sayan selalu memiliki uang yang cukup mana kala secara 
tiba-tiba para anggota menarik simpanannya. Dengan kata lain cadangan likuidits selalu kuat. Di samping itu, uang menganggur (idle) juga diukur untuk memastikan bahwa asetaset yang tidak menghasilkan jangan sampai mengurangi pendapatan Credit Union Keling Kumang Branch Office Sayan.

a. Likuditas terhadap simpanan saham (L1)

Tujuan: Mengukur kecukupan cadangan tunai likuid untuk memenuhi keperluan penarikan simpanan non saham, setelah memenuhi kewajiban jangka pendek < 30 hari

Dari hasil perhitungan pada tahun 2016 sebesar $48 \%$, persentase ini menunjukkan tidak idealnya indikator L1 dengan kriteria tidak ideal / tidak sehat, artinya pada tahun 2016 likuiditas terhadap simpanan saham berarti dalam kondisi yang tidak stabil karena nilai persentasenya lebih dari standar ideal rasio PEARLS $20 \%$.

Pada tahun 2017 sebesar 39\%, persentase ini menunjukkan tidak idealnya indikator L1 dengan kriteria tidak ideal / tidak sehat, artinya pada tahun 2017 likuiditas terhadap simpanan saham berarti dalam kondisi yang tidak stabil karena nilai persentasenya lebih dari standar ideal rasio PEARLS $20 \%$.

Pada tahun 2018 43\%, persentase ini menunjukkan tidak idealnya indikator L1 dengan kriteria tidak ideal / tidak sehat, artinya pada tahun 2018 likuiditas terhadap simpanan saham berarti dalam kondisi yang tidak stabil karena nilai persentasenya lebih dari standar ideal rasio PEARLS $20 \%$.

Kesimpulannya untuk likiuditas terhadap simpanan saham pada tahun 2016-2018 persentase ini menunjukkan Tidak idealnya indikator L1 dengan kriteria tidak ideal / tidak sehat, artinya di tahun 2016-2018 tingkat persentase likuditas terhadap simpanan saham dalam kondisi tidak stabil.

b. Aset-aset Likuid yang Tidak Menghasilkan/Total Aset (L3)

Tujuan: mengukur persentase total aset yang diinvestasikan di dalam nomor perkiraan (account) likuid yang tidak menghasilkan .

Dari hasil perhitungan pada tahun 2016 sebesar $0 \%$, persentase ini menunjukkan Idealnya indikator L3 dengan kriteria ideal / sehat artinya pada tahun 2016 aset-aset likuid yang tidak menghasilkan terhadap total aset berarti dalam kondisi yang ideal / sehat karena nilai persentasenya $0 \%$ dari standar ideal rasio PEARLS $<1 \%$.

Pada tahun 2017 sebesar 0\%, persentase ini menunjukkan Idealnya indikator L3 dengan kriteria ideal / sehat artinya pada tahun 2017 aset-aset likuid yang tidak menghasilkan terhadap total aset berarti dalam kondisi yang ideal / sehat karena nilai persentasenya $0 \%$ dari standar ideal rasio PEARLS $<1 \%$.

Pada tahun $20181 \%$, persentase ini menunjukkan Idealnya indikator L3 dengan kriteria ideal / sehat artinya pada tahun 2018 aset-aset likuid yang tidak menghasilkan terhadap total aset berarti dalam kondisi yang ideal / sehat karena nilai persentasenya $1 \%$ dari standar ideal rasio PEARLS $<1 \%$.

Kesimpulannya untuk Aset-aset likuid yang tidak menghasilkan terhadap total aset pada tahun 2016-2018 persentase ini menunjukkan idealnya indikator L3 dengan kriteria ideal / sehat, artinya di tahun 2016-2018 tingkat persentase aset-aset likuid yang tidak menghasilkan terhadap total aset dalam kondisi ideal / sehat.

\section{Tanda-Tanda Pertumbuhan (Sign of Growth)}

Indikator mengukur pertumbuhan terkini anggota Credit Union Keling Kumang Branch Office Sayan

a. Pertumbuhan anggota (S10)

Tujuan: mengukur pertumbuhan anggota Credit Union Keling Kumang Branch Office Sayan

Dari hasil perhitungan, pada tahun 2016 sebesar $2 \%$, persentase ini menunjukkan tidak idealnya indikator S10 dengan kriteria tidak ideal / tidak sehat, artinya pada tahun 2016 pertumbuhan anggota berarti dalam kondisi yang tidak stabil karena nilai persentasenya kurang dari standar ideal rasio PEARLS $>12 \%$. Pada tahun 2017 sebesar 3\%, persentase ini menunjukkan tidak idealnya indikator S10 dengan kriteria tidak ideal / tidak sehat, artinya 
pada tahun 2017 pertumbuhan anggota berarti dalam kondisi yang tidak stabil karena nilai persentasenya kurang dari standar ideal rasio PEARLS $>12 \%$.

Pada tahun 2018 5\%, persentase ini menunjukkan tidak idealnya indikator S10 dengan kriteria tidak ideal / tidak sehat, artinya pada tahun 2016 pertumbuhan anggota berarti dalam kondisi yang tidak stabil karena nilai persentasenya kurang dari standar ideal rasio PEARLS $>12 \%$.

Kesimpulannya untuk pertumbuhan anggota pada tahun 2016-2018 persentase ini menunjukkan Tidak idealnya indikator S10 dengan kriteria tidak ideal / tidak sehat, artinya pertumbuhan anggota dalam posisi yang tidak stabil karena mengalami penurunan dari standar idealnya.

b. Pertumbuhan total aset (S11)

Tujuan: Untuk Mengukur pertumbuhan terkini dari aset Credit Union Keling Kumang Branch Office

Dari hasil perhitungan, pada tahun 2016 sebesar $1 \%$, persentase ini menunjukkan tidak idealnya indikator S10 dengan kriteria tidak ideal / tidak sehat, artinya pada tahun 2016 pertumbuhan total aset berarti dalam kondisi yang tidak stabil karena nilai persentasenya kurang dari standar ideal rasio PEARLS $3,13 \%$.

Pada tahun 2017 sebesar 1\%, persentase ini menunjukkan tidak idealnya indikator S10 dengan kriteria tidak ideal / tidak sehat, artinya pada tahun 2017 pertumbuhan total aset berarti dalam kondisi yang tidak stabil karena nilai persentasenya kurang dari standar ideal rasio PEARLS 3,13\%.

Dan untuk $20181 \%$, persentase ini menunjukkan tidak idealnya indikator S10 dengan kriteria tidak ideal / tidak sehat, artinya pada tahun 2018 pertumbuhan total aset berarti dalam kondisi yang tidak stabil karena nilai persentasenya kurang dari standar ideal rasio PEARLS 3,13\%.

Kesimpulannya untuk pertumbuhan total aset pada tahun 2016-2018 persentase ini menunjukkan Tidak idealnya indikator S11 dengan kriteria tidak ideal / tidak sehat, artinya pertumbuhan total aset dalam posisi yang tidak stabil karena mengalami penurunan dari standar idealnya.

\section{KESIMPULAN}

1. Berdasarkan analisis data yang dilakukan dapat ditarik kesimpulan untuk menjawab rumusan masalah dari penelitian yang dilakukan peneliti pada periode tahun 2016-2018 yaitu yang pertama bisa ditarik kesimpulan bahwa kinerja keuangan Credit Union Keling Kumang Kantor Cabang Sayan ketika dinilai berdasrkan PEARLS (Protection, Effective Financial Structur, Asset Qulity, Rates Of Return And Cost, Liquidity, dan Sign Of Growth)

2. Untuk tahun 2016 rasio Perlindungan untuk P1 dan P2 tidak ideal, Struktur Keuangan Efektif untuk E1 tidak ideal, E5 ideal, E7 ideal, E8 ideal, Kualitas Aset untuk A1 tidak ideal, A2 ideal, Nilai Pengembalian dan Biaya untuk R7 ideal R9 ideal, Likuiditas untuk L1 tidak ideal L3 Ideal, Tanda-tanda Pertumbuhan untuk S10 idak ideal S1 1 tidak ideal.

3. Untuk tahun 2017 rasio Perlindungan untuk P1 dan P2 tidak ideal, Struktur Keuangan Efektif untuk E1 tidak ideal, E5 ideal, E7 ideal, E8 ideal, Kualitas Aset untuk A1 tidak ideal, A2 ideal, Nilai Pengembalian dan Biaya untuk R7 ideal R9 ideal, Likuiditas untuk L1 tidak ideal L3 Ideal, Tanda-tanda Pertumbuhan untuk S10 idak ideal S1 1 tidak ideal.

4. Untuk tahun 2018 rasio Perlindungan untuk P1 dan P2 tidak ideal, Struktur Keuangan Efektif untuk E1 tidak ideal, E5 ideal, E7 ideal, E8 ideal, Kualitas Aset untuk A1 tidak ideal, A2 ideal, Nilai Pengembalian dan Biaya untuk R7 ideal R9 ideal, Likuiditas untuk L1 tidak ideal L3 Ideal, Tanda-tanda Pertumbuhan untuk S10 idak ideal S11 tidak ideal. Untuk struktur keuangan yang efektif E5, E7, E8, nilai pengembalian dan biaya R7, R9, likuiditas L3 ideal, presentasenya sudah ideal / sehat karena mencapai kreteria PEARLS yang berarti mengalami peningkatan kinerja keuangan yang cukup signifikan ini artinya kemajuan yang sangat baik pada Credit Union Keling Kumang Kantor Cabang Sayan. 


\section{REFERENSI}

Franseda. 2017. Komparatif Capaian Indikator Pearls Pada Credit Union Keling Kumang Tempat Pelayanan Rumah Punyung Di Sintang.

Harahap Sofyan Syafri. 2011. Teori Akuntansi Edisi Revisi 2011. Jakarta: Rajawali Pers.

Kasmir. 2016. Analisis Laporan Keuangan. Jakarta: Raja Grafindo Persada

Munaldus, Karlena dan Herlina. 2014. Kiat Mengelola Credit Union. Elexmedia.

Munawir. 2010. Analisis laporan Keuangan Edisi keempat. Cetakan Kelima Belas. Yogyakarta: Liberty.

Richardson, David C. 2009. PEARLS Monitoring System. USA: WOCCU.

Sugiyono. 2017. Metode Penelitian Kuantitatif, Kualitatif, dan $R \& D$. Bandung: Alfabeta, CV.

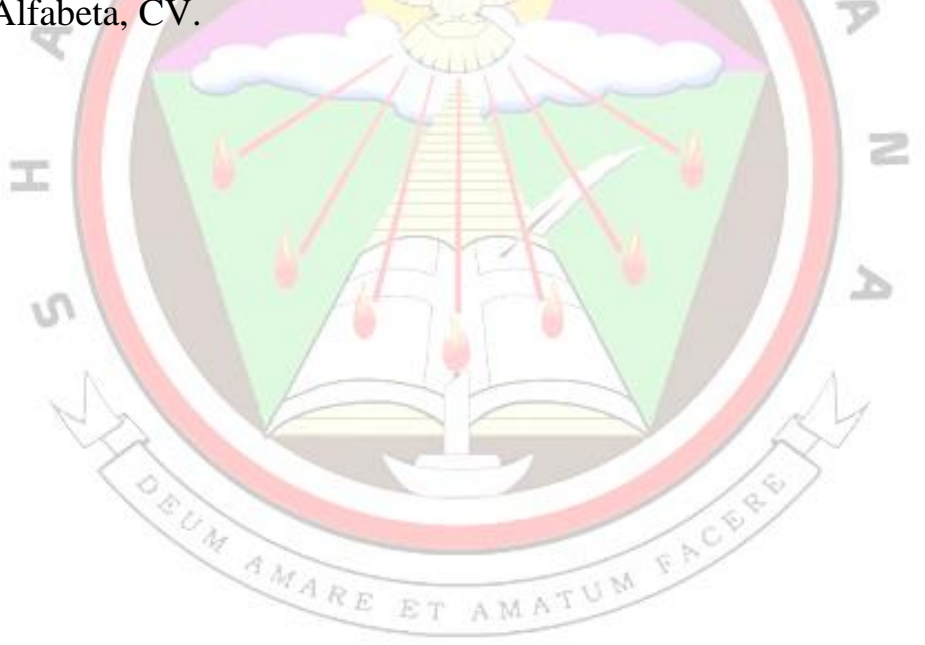

